\title{
A CONSTRUÇÃO HERMENÊUTICA DO PRINCÍPIO DA LIBERDADE RELIGIOSA NO BRASIL
}

\author{
Arthur Cabral Gonçalves ${ }^{1}$
}

RESUMO: O trabalho analisa as motivações históricas que suscitaram o surgimento do valor da liberdade religiosa, consagrado no rol de princípios do Estado Constitucional. Os movimentos constitucionalistas do século XVII traçaram caminhos distintos, quanto à concepção da laicidade, provocando o surgimento de dois modelos que irão influenciar as diferentes visões acerca da religião no espaço democrático. No Brasil, as razões históricas conduziram o sistema constitucional a manter-se equidistante, mas, igualmente, favorável ao fenômeno religioso, como componente cultural imprescindível para a formação do País, o que deve ser considerado pela atividade interpretativa relativas às questões que envolvem este controverso ambiente.

Palavras-chave: Hermenêutica, princípio, liberdade religiosa, laicidade, Estado Constitucional.

\section{THE HERMENEUTIC CONSTRUCTION OF THE PRINCIPLE OF RELIGIOUS LIBERTY IN BRAZIL}

\begin{abstract}
The paper analyzes the historical motivations that gave rise the value of religious freedom, enshrined among the principles of the Constitutional State. The constitutionalist movements of the seventeenth century drew different paths regarding the conception of laicity, provoking the emergence of two models that will influence the different visions about religion in the democratic space. In Brazil, historical reasons have led the constitutional system to remain equidistant, but also favorable to the religious phenomenon, as a cultural component essential for the formation of the Country, which should be considered by the interpretation around the issues involved in this controversial environment.
\end{abstract}

Keywords: Hermeneutic, principle, religious freedom, laicity, Constitutional State.

\footnotetext{
${ }^{1}$ Mestrando em Direito, com área de concentração em Constituição e Garantia de Direitos (UFRN). Especialista em Direito Eleitoral (PUC-MG - 2018). Bacharel em Direito (UFRN - 2014).
} 


\section{INTRODUÇÃO}

Ao se tratar sobre o princípio da liberdade religiosa, alude-se, não raramente, à laicidade do Estado e à desvinculação do sistema jurídico de qualquer preceito fundamentado na crença ou em alguma profissão de fé. Sob essa perspectiva, o Estado seria responsável por se manter isento e totalmente neutro em matéria religiosa, deixando as convicções e manifestações ao arbítrio de cada indivíduo, dando origem ao que se denominou de Estado laico, em sentido amplo.

A ideia de laicidade surgiu no contexto da reivindicação dos direitos de liberdade, que eclodiram no seio dos movimentos constitucionalistas, sobretudo nos que resultaram na independência dos Estados Unidos (1776) e na Revolução Francesa (1789). A construção do Estado de Direito implicava igualmente na construção de um Estado isento no que diz respeito às convicções de pensamento e de crença, concedendo aos seus nacionais autonomia e liberdade sobre as questões atinentes à fé, seja no foro íntimo, seja na sua expressão e vivência.

Ocorre que a dissociação entre poder e religião suscitou o pensamento de que a crença deveria permanecer alheia às deliberações da sociedade, na medida em que o Estado se mantinha distante da fé, o que destinaria o culto a se restringir à esfera privada. Nesse sentido, compreende-se que os preceitos religiosos, por se basearem em verdades reveladas e imutáveis, tenderiam a engessar o pensamento social e tolher as liberdades democráticas que se almejavam construir.

O presente trabalho objetiva demonstrar, à luz das raízes históricas, as concepções que originaram a valoração da liberdade de religião e a sua inclusão no rol de direitos fundamentais do homem e do cidadão, a serem consagradas pelo Estado de Direito. Embora cada nação possua peculiaridades próprias, os movimentos constitucionalistas norte-americano e francês são utilizados como arquétipos de modelos antagônicos de compreensão do papel da religião no Estado laico. Estas duas tradições influenciaram a interpretação do princípio da liberdade religiosa nos Estados constitucionais ocidentais, incluindo o Brasil.

Sob este prisma, serão analisadas, ainda, a percepção da religião na construção histórica do sistema constitucional brasileiro e a forma como a liberdade de crença é apresentada pela tradição republicana, mantida pela Constituição de 1988, sobretudo no que diz respeito à sua influência nas questões que circundam a sociedade. O estabelecimento de tais 
pressupostos se demonstra fundamental para se alcançarem resoluções satisfatórias ante o crescente número de hard cases que dizem respeito à liberdade de fé e ao espaço a ser ocupado pelas múltiplas visões de mundo religiosas em uma sociedade plural e democrática.

\section{O SURGIMENTO E A CONSAGRAÇÃO DA LIBERDADE RELIGIOSA}

A concepção de laicidade do Estado Constitucional não surgiu numa atitude inicial de contraposição à religião, mas, por outro lado, nasceu em clara compatibilidade com a visão cristã, a qual, desde o fim da antiguidade, teve uma participação fundamental na formação do pensamento ocidental. No ambiente universitário, criado pela Igreja para o desenvolvimento dos métodos científicos e do pensamento filosófico (WOODS JR., 2008, p. 42), muitos teóricos, como - por exemplo - John Locke ${ }^{2}$ e Immanuel Kant ${ }^{3}$, buscaram adequar as suas convicções de fé aos seus parâmetros racionais acerca do mundo, da filosofia, da ciência e do direito.

A história da civilização cristã, motivada pela sua origem periférica e pela contestação inicial acerca do culto à religião do imperador romano, implicou na visão, já no período da Idade Média, de que o Rei, embora estivesse legitimado sobre um direito divino, tinha o poder limitado às questões políticas e não poderia se imiscuir na doutrina, o que competiria à estrutura eclesiástica. WOODS JR. (2008, p. 179) discorre que o Papa Gregório VII, no século XI, já tinha dado um passo decisivo para a separação entre Igreja e Estado quando definiu que o Rei era um simples fiel, sem nenhuma função religiosa além das que tinha qualquer outro cristão.

Desse modo, a sociedade pautada pelo cristianismo fazia germinar os primeiros sinais de autonomia entre o poder temporal do Estado e o poder espiritual da religião, o que era impensável no contexto político da antiguidade. A Reforma Protestante do século XVI, que fragmentou a unidade da organização cristã na Europa, evidenciou ainda mais a necessidade de garantir a liberdade entre as diferentes denominações - embora a instituição política ainda se

\footnotetext{
2 "Embora suas ideias enquadrem-se no Direito Racional, nem por isso Locke ficou alheio ou ficou contra as ideias cristãs.” (ALTAFIN, 2007, p. 10) Para Locke, “a religião surge como uma sociedade civil publicamente relevante, embora distinta do Estado. Este, mesmo se subordinado aos princípios divinos, não poderia imiscuir-se nas questões eclesiásticas nem na consciência individual”. (MACHADO, 2013, p. 21)

3 "Kant era devoto e não considerava suas ideias hostis à religião. Acreditava que elas libertariam a fé de uma confiança totalmente inadequada na razão”. (ARMSTRONG, 2009, p. 111)
} 
mantivesse unida a determinadas estruturas religiosas ${ }^{4}$, - ao preceituar uma releitura do cristianismo, emancipada dos ditames traçados pela Igreja de Roma. ${ }^{5}$

Nesse sentido é que a liberdade religiosa foi consentida nos Estados Unidos da América, desde a sua formação no século XVIII, consoante assevera SANTOS JÚNIOR (2008, p. 2):

Nos Estados Unidos, [...] vê-se claramente que a intenção primeira dos constitucionalistas foi a de proteger as igrejas da interferência governamental, sobretudo para garantir proteção ao pluralismo religioso que marcou a história norteamericana desde os seus primórdios.

Com efeito, a origem dos Estados Unidos da América - os quais recebiam inúmeros refugiados dos conflitos religiosos que ocorriam na Europa em razão da fragmentação da unidade cristã e das disputas entre os Estados Absolutistas - está calcada na compreensão de "que todos os homens são criados iguais, que são dotados pelo Criador de certos Direitos inalienáveis, que entre estes estão a Vida, a Liberdade e a busca da Felicidade.”6

Sob estes direitos inalienáveis e inatos do homem está erigido o Estado Constitucional norte-americano e a sua vocação para a liberdade, sobretudo de consciência e de crença, as quais não podem ser objetos de interferência pelo ente governante. A Primeira Emenda à Constituição assevera essa intenção dos founding fathers ao assegurar que "O Congresso não deverá fazer qualquer lei a respeito de um estabelecimento de religião, ou proibir o seu livre exercício [...]”.

Sendo assim, não se verifica uma inimizade entre religião e Estado, mas a garantia de uma separação que possa conceder autonomia às diversas matizes religiosas, sem que haja

\footnotetext{
4 “No século XVII, ainda manchado pelas guerras religiosas, houve quem estivesse na vanguarda da luta por uma liberdade religiosa ampla. Roger Williams, pastor batista, apregoava já naquela época a separação da igreja e do Estado e reclamava uma absoluta liberdade religiosa, não só para os cristãos, mas também para os judeus, muçulmanos e pagãos, que deveriam ter os mesmos direitos civis e políticos que os cristãos, pois - segundo dizia - a consciência do homem pertence a ele mesmo e não ao Estado.” (SANTOS JÚNIOR, 2008, p. 2)

5 "Como os homens de seu tempo, os reformadores refletiam as mudanças que estavam ocorrendo. Ao deixar a Igreja Católica Romana, fizeram uma das pioneiras declarações de independência que pontuaria a história ocidental a partir desse momento. Conforme veremos, o novo etos requeria autonomia e liberdade total, e era isso que os reformadores protestantes reivindicavam para os cristãos do mundo modificado, que precisavam ser livres para ler e interpretar a Bíblia, como bem entendessem, sem o controle punitivo da Igreja.” (ARMSTRONG, 2009, p. 99100)

${ }^{6}$ ESTADOS UNIDOS DA AMÉRICA. Declaration of Independence, Preamble (tradução livre). “[...] that all men are created equal, that they are endowed by their Creator with certain unalienable Rights, that among these are Life, Liberty and the pursuit of Happiness.”
} 
possibilidade de limitações arbitrárias impostas pelo governante. Prevalece, igualmente, em consonância com o conjunto de direitos do homem e do cidadão, a proteção da liberdade individual de cada pessoa de discernir acerca da visão de mundo religiosa, sem coerção estatal.

A França foi igualmente influenciada pela separação dos vínculos entre Estado e religião sob o ponto de vista cristão, visto que, mesmo que o Ancien Régime tenha mantido laços estreitos com a Igreja Católica, muitos franceses, inclusive nobres, já haviam aderido, antes da Revolução de 1789, a correntes da Reforma Protestante, o que provocou tensão e alguns conflitos.

Por essa razão, o Rei Henrique II decretou o Edito de Nantes (1598), a fim de garantir a convivência pacífica entre os diferentes grupos religiosos e a possibilidade de culto pelos não católicos. Ocorre que a perseguição àqueles que não professavam a fé católica foi restaurada e intensificada por Luis XIV, a partir do Edito de Fontainebleau (1685), causando a desaprovação do Papa Inocêncio XI e a irresignação dos súditos, os quais já começavam a ser impulsionados pelos ideais libertários dos iluministas. (ALVES, 2008, p. 100-101).

Em que pese inúmeros membros da Igreja Católica tenham aproximado suas crenças aos ideais de liberdade, igualdade e fraternidade, a opressão do Regime Absolutista causou um estranhamento entre a Igreja e os revolucionários, após a queda da Bastilha. Estes propuseram uma nova religião nacionalista, desapegada de qualquer tradição remanescente da monarquia, mas assentada no culto à Razão, com influência da filosofia racionalista (SABORIT, 2009, p. 116). Foi introduzida a celebração com rituais simbólicos que adaptavam o culto católico à chamada “Missa decadária”, marcada pela entronização da estátua da Liberdade na Catedral de Notre-Dame, a qual incorporava a divindade da Sagrada Razão (Idem, p. 120).

Os racionalistas acreditavam que era necessário "libertar-se das causas da ignorância para com isso libertar-se das causas do medo e da esperança e, ao fazê-lo, libertar-se de seus efeitos políticos e religiosos”, trazendo a ideia de que "o poderio supersticioso da religião" deveria permanecer longe do pensamento social (CHAUÍ, 1995, p. 35). Segundo SABORIT (2009, p. 109), os racionalistas defendiam que “o desenvolvimento da razão pressuporia a garantia da liberdade. Era óbvio que a liberdade não poderia aliar-se à religião porque, ao prescindir ostensivamente da razão, esta prejudicava a manifestação inequívoca da razão e da ciência.”. Essa libertação religiosa era evocada no novo culto inaugurado, o qual não 
homenageava divindades ocultas e transcendentes, mas a própria Razão livre, assentada no homem.

Os instáveis anos iniciais da Revolução Francesa resultaram na tentativa de nacionalizar a crença, provocando a contestação da Igreja e o crescimento da popularidade do ateísmo baseado nessas premissas e nesses rituais racionalistas (SABORIT, 2009, p. 101). A secularização e a perseguição à fé católica, que perdurou incessantemente até 1801, conduziram, segundo ALVES (2008, p. 102), “à laicização absoluta do Estado”, cuja marco definitivo foi a promulgação da Lei de Separação das Igrejas e do Estado (1905), com o apoio dos parlamentares anticlericais.

Por tais razões históricas é que, na Constituição atual da França, a laicidade encontrase no artigo primeiro ${ }^{7}$, como corolário da igualdade entre os cidadãos, “independentemente de origem, raça ou religião", tornando o país notável em virtude de a religião ter sido gradativamente afastada do cenário público. MACHADO (2013, p. 23) descreve que a laicidade francesa atual "supõe uma concepção não religiosa do Estado, da soberania e da cidadania, implicando a remoção das manifestações religiosas da esfera pública e a sua circunscrição à esfera privada, no seu domínio mais pessoal de decisão íntima”. Ou seja, prevalece o pensamento de que "quando a religião permanece na esfera privada, todos os cidadãos são iguais na esfera pública”. ${ }^{8}$

Desse modo, a formação histórica do constitucionalismo nos exemplos utilizados Estados Unidos e França - denotam as diferentes concepções que irão influenciar na construção hermenêutica, em perspectivas claramente distintas, quanto à concretização da liberdade religiosa como princípio fundamental do Estado Democrático de Direito.

\section{OS PRESSUPOSTOS INTERPRETATIVOS DAS CONCEPÇÕES ACERCA DO PRINCÍPIO DA LIBERDADE RELIGIOSA}

\footnotetext{
7 CONSTITUIÇÃO FRANCESA, Art. $1^{\circ}$ (Tradução livre) “A França é uma República indivisível, laica, democrática e social. Assegura a igualdade de todos os cidadãos perante a lei sem distinção de origem, raça ou religião. Respeita todas as crenças. [...]”.

${ }^{8}$ Tradução livre. "Quand la religion reste dans la sphère privée, tous les citoyens sont égaux dans la sphère publique.” ÍSLANDS et al., 2015, p. 11.
} 
O princípio da liberdade religiosa foi concebido desde a gênese do Estado Democrático de Direito, como um valor fundamental à nova ordem jurídica, inaugurada pelo constitucionalismo, e consagrado entre os direitos do homem e do cidadão. No entanto, as razões históricas discorridas no capítulo anterior fazem denotar que a concepção deste princípio traz variações bastante diversas, nos diferentes sistemas constitucionais.

MIRANDA (In MARTINS FILHO; NOBRE, 2011, p. 107-111) prescreve que a relação entre Estado democrático laico - em sentido amplo - e religião foi traçada, seguindo dois modelos claramente distintos, cujos pressupostos merecem ser tratados no presente estudo: o constitucionalismo americano influenciou o modelo de liberdade a partir da não identificação do Estado com nenhuma expressão religiosa, o que é conhecido como Estado laico (stricto sensu); já o constitucionalismo francês deu origem à concepção de liberdade vinculada à negação da atuação da religião no espaço público, restrigindo-a ao ambiente privado, o que denomina Estado laicista.

\subsection{O ESTADO LAICO}

A laicidade norte-americana, compreendida dentro de uma ótica cristã, assenta-se na sua concepção filosófico-teológica de livre-arbítrio do ser humano e na ideia de que a Verdade transcendente e universal, originária no Ser Divino (o Logos), é o objeto central de investigação da razão e da ciência humanas. ${ }^{9}$ Desse modo, o poder do Estado estaria fundado no direito natural, emanado da Razão Criadora, a qual concedeu ao homem a sua capacidade de pensar e de conhecer, através da sua própria razão. Como discorrem MENDES, COELHO E BRANCO (2007, p. 308).

O cristianismo marca impulso relevante para o acolhimento da ideia de uma dignidade única do homem, a ensejar uma proteção especial. O ensinamento de que o homem é criado à imagem e semelhança de Deus e a ideia de que Deus assumiu a condição humana para redimi-la imprimem à natureza humana alto valor intrínseco, que deve nortear a elaboração do próprio direito positivo.

\footnotetext{
9 “A visão judaico-cristã do mundo tem a seu favor o facto de colocar o Verbo, o Logos ou a Razão como princípio criador, conformador e estruturante de todas as coisas. Por esse motivo ela está em condições para fornecer o fundamento axiomático último da racionalidade e da actividade científica.” (MACHADO, 2013, p. 104.)
} 
Assim, o cristianismo compreende que a autoridade política está vinculada obrigatoriamente ao dever de expressar a ordem moral transcendente, universal e absoluta, de origem divina. Ao Estado, por conseguinte, não cabe exercer uma função religiosa, mas promover o bem comum e a proteção do ser humano, cuja dignidade está assentada no Criador. É nesse sentido que Santo Agostinho, já no século IV, escrevera acerca da existência de duas cidades distintas e coexistentes e, ao mesmo tempo, acerca da necessidade de que "Cidade dos Homens”, marcada pelo pecado e pelas arbitrariedades do ser humano, fosse construída a serviço das leis universais divinas emanadas através da “Cidade de Deus”, “edificada sobre o amor e para a glória de Deus”. (MACHADO, 1996, p. 25)

É importante recordar que os cristãos sofreram duras perseguições, durante cerca de três séculos, por não se submeterem ao culto ao Imperador e à religião do Império Romano. Em que pese a Idade Média e a Idade Moderna tenham sido marcadas por vastos exemplos de regimes despóticos que mantinham estreitos laços com o clero, a visão cristã teve um importante papel na condução de seus crentes a apoiarem os movimentos democráticos liberais, que consagraram o direito fundamental à liberdade de religião.

O valor da liberdade se torna fundamental para que o ser humano, enquanto considerado imagem e semelhança divina, possua autonomia sobre a sua vida e sua crença, sem que haja imposição pela autoridade estatal. Esta última não possui condições de determinar o que seria a verdade em matéria de fé, mas se limita tão somente ao papel de permitir e garantir que as diferentes manifestações religiosas possam ser expressadas na sociedade.

Nesse sentido, descreve MORAES (In MARTINS FILHO; NOBRE, 2011, p. 59) que o Estado democrático instaura a liberdade religiosa na medida em que:

Abandona a pretensão de encontrar o bem verdadeiro para encaminhar os cidadãos para ele e procura apenas garantir um espaço de liberdade e de convivência pacífica em que cada um possa ser respeitado nos seus direitos fundamentais e orientar a vida de acordo com as próprias convicções.

Para RHONHEIMER (In MARTINS FILHO; NOBRE, 2011, p. 81), “em matéria de religião, o Estado laico não utiliza critérios de verdade, mas trata as religiões aplicando critérios de justiça política, que incluem imparcialidade e neutralidade”. Sendo assim, não se pretende diminuir a importância da presença da cultura religiosa no ambiente público, inclusive na 
formação moral de cada indivíduo, mas conceder a cada um, com sua própria visão de mundo, a possibilidade de contribuir para o desenvolvimento da sociedade.

Pode-se concluir seguindo o disposto por ARENDT (2007, p. 265):

A secularização significa apenas a separação entre Igreja e Estado, entre religião e política, e isso, do ponto de vista religioso, implica um retorno à inicial atitude cristã de dar 'a César o que é de César e a Deus o que é de Deus', mais que uma perda de fé e transcendência ou um novo enfático interesse nas coisas desse mundo.

Em outras palavras, o Estado laico, ao emancipar-se da religião, não visa abster-se totalmente no tocante aos valores advindos das crenças, mas reconhece a importância vital da religião na sociedade e na visão de mundo de seus cidadãos, razão pela qual possui o dever de assegurar a sua participação, sem fazer adesão a nenhuma delas. Não cabe ao Estado definir se alguma delas está correta ou equivocada, mas tão somente garantir a liberdade e a igualdade de sua manifestação, à luz dos princípios do Estado Democrático de Direito.

\subsection{O ESTADO LAICISTA}

O divórcio entre a democracia francesa e a religião decorreu dos inúmeros conflitos entre o clero e os revolucionários, que almejavam nacionalizar a fé e libertar-se de dogmas transcendentes, impostos pelo poder da estrutura eclesial. Este movimento foi deveras influenciado pelo pensamento racionalista, o qual pretendia alcançar a Verdade estritamente pela via da razão humana, a fim de assentar conceitos universalmente aceitos pela observação científica e separados de convicções de cunho religioso.

Para Hugo Grotius, um dos mais notáveis filósofos e juristas ligados à Escola de Direito Natural Racionalista, “certos valores estão suficientemente radicados na consciência e na razão humanas” (MACHADO, 2013, p. 23), de modo que não se tornaria necessário adentrar em postulados alcançados apenas por meio da crença ou de pressupostos metafísicos, sem que se submeta à comprovação pela via do rigor científico. Em outras palavras, a visão racionalista objetivava construir, a partir da razão e da ciência inerentes ao ser humano, os valores universais da sociedade, sem precisar trazer a lume a discussão sobre a existência de Deus. 
Ocorre que o conceito objetivo e racional de Verdade se demonstrou inalcançável pela mera atividade científica do homem, provocando diversos questionamentos quanto à capacidade de se atingir axiomas irrefutáveis, que deveriam ser moralmente aceitos de modo universal, posto que "a ciência não existe à margem das diferentes visões de mundo" (MACHADO, 2013, p. 123). Como observa BARROSO (2001, p. 37), nada assegura que as bases do pensamento e do direito atual "sejam produto inequívoco de um conhecimento racional. Podem expressar apenas a ideologia ou o desejo”.

Com efeito, a ideia de uma racionalidade pura e universal esbarrou em dois problemas insolúveis. O primeiro deles é a limitação da própria razão e do alcance do conhecimento científico, sobretudo quando se depara com questões interiores à condição humana e acerca do fundamento último do pensamento científico. Ora, sendo assim, os fundamentos últimos da moral e da própria razão, como, do mesmo modo, a origem do universo, da vida e do homem remetem inevitavelmente para uma interrogação metafísica, que extrapola o conteúdo tangível empiricamente (MACHADO, 2013, p. 120).

O segundo impasse enfrentado foi a incapacidade de a ciência garantir que o observador - ainda mais limitados pela própria razão - alcançasse uma posição neutra perante o seu objeto, com especial relevo para matérias de cunho moral e religiosa. Não é necessário empreender maiores esforços para se verificar que qualquer conhecimento "não é uma foto, flagrante incontestável da realidade. Todos os objetos estão sujeitos à interpretação”, especialmente quando se depara com argumentos morais ou religiosos (BARROSO, 2001, p. 17).

Sendo assim, a declaração de independência da ciência e da razão perante as demais visões de mundo não passa de - como verifica Jürgen Habermas - uma "propaganda pseudocientífica” (MACHADO, 2013, p. 123) e, por conseguinte, o mundo secularizado não aponta para uma neutralidade universal e consensual, mas se apresenta como "uma nova religião”, a qual demanda “conversão e entrega total”. (ARMSTRONG, 2009, p. 139). Assim, do ponto de vista da liberdade religiosa, o secularismo baseado em pressupostos laicistas nada mais é do que mais uma nova visão de mundo, assentada em razões metafísicas, que visa substituir a visão de mundo religiosa do espaço público sem, no entanto, apresentar credenciais que o tornam superior.

Portanto, ao invés de formar um Estado neutro, que denotasse a liberdade de pensamento e de crença de todos os nacionais, o laicismo se aparta do fenômeno religioso, considerando-o indispensável ou, até mesmo, prejudicial à formação do Estado democrático, de forma a 
promover uma visão de mundo que “tenta impor hoje, com força do poder estatal, a 'verdade' da não existência ou irrelevância de Deus, bem como da consequente irrelevância - e até mesmo nocividade - da religião” (RHONHEIMER, In: MARTINS FILHO; NOBRE, 2011, p. 111.), o que provoca uma interferência arbitrária na autonomia dos cidadãos de discernirem de acordo com a sua própria convicção de consciência e de crença.

\section{O PRINCÍPIO DA LIBERDADE RELIGIOSA NA CONSTITUIÇÃO DE 1988}

A Constituição da República Federativa do Brasil alude a uma perspectiva transcendental ao invocar a proteção divina no seu texto preambular ${ }^{10}$. Em que pese não possua força normativa, como já esclareceu o Supremo Tribunal Federal, o texto introdutório indica os valores caros à nação, que necessitam ser observados pela hermenêutica constitucional ${ }^{11}$.

Segundo MENDES, COELHO E BRANCO (2007, p. 82), “o preâmbulo da Constituição de 1988 externa a 'crença impessoal' do constituinte brasileiro de que é possível invocar e receber a proteção de Deus para bem cumprir a sua relevante missão”. Não se pretende iniciar uma discussão teológica acerca da existência, da natureza, da acepção e da realidade divinas, mesmo porque o Estado não dispõe de elementos para tanto. Por outro lado, torna-se evidente que "a neutralidade resultante [do Estado] assume um fundamento teísta, apontando para uma valoração positiva da dimensão espiritual do homem, com reflexos na interpretação constitucional” (MACHADO, 2013, p. 142).

Essa perspectiva se coaduna com a tradição constitucional pátria, a qual, com raros momentos de exceção, sempre primou pela garantia da liberdade religiosa e a laicidade do Estado, com a sua separação de qualquer denominação, ao mesmo tempo que introduziu

\footnotetext{
10 Preâmbulo da Constituição da República Federativa do Brasil: “Nós, representantes do povo brasileiro, reunidos em Assembléia Nacional Constituinte para instituir um Estado Democrático, destinado a assegurar o exercício dos direitos sociais e individuais, a liberdade, a segurança, o bem-estar, o desenvolvimento, a igualdade e a justiça como valores supremos de uma sociedade fraterna, pluralista e sem preconceitos, fundada na harmonia social e comprometida, na ordem interna e internacional, com a solução pacífica das controvérsias, promulgamos, sob a proteção de Deus, a seguinte Constituição da República Federativa do Brasil”. (grifo nosso)

11 “Como vetor hermenêutico, são indiscutíveis, se não mesmo imprescindíveis, os préstimos do preâmbulo, na medida em que nele e por ele se expressam o ethos e o telos da Sociedade e da sua Lei Fundamental, dados materiais de partida que funcionam para o intérprete como verdadeira condição de possibilidade do compreender constitucional. [...] No Brasil, embora escassos os julgados que enfrentaram esse tema, parece igualmente consolidado no STF o entendimento de que o preâmbulo, não sendo preceito central da Constituição e, por isso, carecendo de valor normativo per se, é desprovido de força para sustentar pretensões fundadas no seu palavreado [...]” MENDES; COELHO; BRANCO, 2007, p. 78-79.
} 
institutos jurídicos propiciadores da cooperação entre o ente estatal e as manifestações religiosas, em benefício do interesse público (ALVES, 2008, p. 59-62).

Com efeito, a ligação entre os laços culturais que formaram o país e a manifestação religiosa sempre foram muito estreitas. Os povos indígenas e os negros, de origem africana, mantiveram em suas raízes forte tradição religiosa, que permeiam até hoje a cultura do país. O Estado português, vinculado à Igreja Católica, iniciou a conquista da nova colônia, tendo por marco inicial a celebração da primeira Missa, assim como contou com a presença e a catequese dos padres jesuítas no apoio fundamental para a colonização e para a formação do País.

Com a Proclamação da República, o Estado se desvinculou da Igreja Católica, através do Decreto 119-A, assinado pelo governo provisório, em 1890, definindo a autonomia entre ambos, de forma que o governo não poderia mais interferir na questões interna corporis da Igreja, ao passo que esta deixava de ser mantida e subvencionada pelo ente público. Sendo assim, vigorou a partir deste Decreto e durante todo o período de vigência da Constituição de 1891 a privatização da organização religiosa, com o objetivo de se consolidar a existência de “uma Igreja livre num Estado livre”. ${ }^{12}$ (ZYLBERSZTAJN, 2012, p. 20-21).

Em que pese tenha se delineada a separação institucional entre ambos, o histórico do constitucionalismo brasileiro não deixará de ser marcado pelo forte apreço às manifestações de cunho religioso e a sua presença no cenário público. A Constituição de 1934 será responsável por inaugurar normas jurídicas que aperfeiçoaram esta nova relação entre a República e as múltiplas crenças, as quais perdurarão até os dias atuais - com rara exceção durante o Estado Novo e, em alguns pontos, no Regime Militar.

ALVES (2008, p. 60-61) descreve as cinco grandes inovações que o constituinte empreendeu no texto da segunda Carta republicana: (1) a invocação preambular divina já mencionada; (2) a implementação da colaboração recíproca em prol do interesse coletivo, a qual não encontrava amparo na separação estabelecida pelo constituinte da primeira carta republicana, o que igualmente permanecerá em 1946, 1967 e 1988; (3) o reconhecimento de efeitos civis às celebrações de casamento religioso, desde que observadas as formalidades impostas pela legislação, mantendo-se até os dias atuais, em deferência à cooperação entre Estado e organizações religiosas em prol do interesse público; (4) a assistência religiosa em

12 É importante destacar que a liberdade requerida e alcançada pela Igreja Católica igualmente foi garantida aos demais cultos, os quais não contavam com o amparo estatal, antes do advento da República. 
instituições públicas de internação coletiva, tais como estabelecimentos militares e hospitais, cujo direito subsistirá até o sistema atual, estando, inclusive, presente no rol de direitos fundamentais da Constituição de 1988; e, por fim, (5) a introdução do ensino religioso de matrícula facultativa nas instituições públicas de ensino, manifestando mais uma clara mudança em relação ao texto constitucional de 1891.

A valorização da fé não contrapõe o Estado brasileiro à liberdade religiosa ou à sua laicidade, mas manifesta claramente a posição de que, em que pese este se mantenha equidistante de todas as denominações religiosas e não faça adesão a nenhum credo, o ordenamento jurídico nacional aprecia o fenômeno religioso enquanto um valor de alto relevo para a compreensão e para o desenvolvimento social, o qual deve ser preservado e garantido aos cidadãos, como um componente intrínseco à sua liberdade, conforme reside positivado no artigo 19, inciso I da Constituição atual. ${ }^{13}$

Nesse diapasão, a norma constitucional, mesmo vedando a promoção de algum credo pelo Estado, possibilita o reconhecimento de manifestações de natureza religiosa, que possuem grande importância para o ambiente público, seja numa garantia de não interferência e de auto-organização (status negativus), seja num dever de prestação do Estado (status positivus) na concretização do exercício da liberdade de religião. ${ }^{14}$

Portanto, pode-se afirmar com clareza que o constituinte originário, seguindo os precedentes históricos, assim como a formação cultural da nação, manifesta expressamente o seu apreço pela religião e pelos valores advindos de preceitos religiosos, sem tolher nem a liberdade de crença dos indivíduos, nem fazer opção por qualquer destas manifestações, sendo um exemplo claro de Estado democrático laico e aconfessional, nos moldes dos Estados Unidos, o que deve ser observado e respeitado na concretização de direitos, cujo mote deve ser a concretização de tal princípio fundamental, especialmente quando se traz à lume os inúmeros casos difíceis que o circundam.

\section{CONCLUSÃO}

\footnotetext{
${ }^{13}$ Nesse diapasão, o artigo 19, inciso I da Constituição Federal, estabelece que: “Art. 19. É vedado à União, aos Estados, ao Distrito Federal e aos Municípios: I - estabelecer cultos religiosos ou igrejas, subvencioná-los, embaraçar-lhes o funcionamento ou manter com eles ou seus representantes relações de dependência ou aliança, ressalvada, na forma da lei, a colaboração de interesse público. (grifo nosso).”

${ }^{14}$ Estas características se depreendem da leitura dos incisos VI a VIII, do artigo $5^{\circ}$ da Constituição Federal, nos quais reside o núcleo do direito fundamental à liberdade de crença na Constituição. Sobre esse tema, MARTINS, p. 356 et seq.
} 
O valor da liberdade religiosa em face da intervenção estatal foi percebido no próprio seio da religião, notadamente pela tradição cristã, o que influenciou a cultura e a política no ocidente. A separação do poder religioso e do poder secular possuiu singular importância para ambas as partes, sobretudo com o surgimento e a consolidação do Estado Democrático de Direito.

A interferência estatal na religião implicava na sua manipulação ao alvedrio do Soberano, o que colocava em xeque a própria pretensão de verdade absoluta que a crença preconizava. Ademais, o pluralismo religioso, potencializado pela Reforma Protestante, tornou ainda mais insustentável a manutenção de uma unidade expressa pela máxima “cujus Regio, ejus religio”, ao passo que se almejava garantir a cada indivíduo para escolher e agir conforme a sua consciência e crença.

Nesse contexto, a liberdade de religião figura entre os mais relevantes direitos de liberdade afirmados pelo constitucionalismo, em contraposição às arbitrariedades do poder estatal. Como certa vez tratou Jellinek, esta busca reside na mais inicial luta pela afirmação dos direitos fundamentais. (TAVARES, p. 635). Todavia, as razões históricas irão traçar diferentes relações entre o sistema constitucional e a crença.

Os founding fathers reconheceram na Constituição americana e no seu sistema jurídico-constitucional que a liberdade religiosa não implicava na expulsão da fé do cenário público, mas na garantia que o poder estatal deveria propiciar a todas as diferentes denominações a possibilidade de se expressar de forma isonômica, à luz dos valores de liberdade e de igualdade, cujos pressupostos estão assentados na visão de mundo cristã acerca da dignidade da pessoa humana, originada no Logos divino.

Já o acirramento entre o clero e os revolucionários, aliado ao crescimento do racionalismo no âmbito filosófico, com a tentativa de buscar uma explicação do mundo sem entrar no mérito de questões metafísicas, traçaram na “filha mais velha da Igreja” - a França um caminho diverso, na qual a laicidade estatal se tornou sinônimo da privatização da fé, independentemente do credo professado, isto é, a sua restrição ao foro íntimo, sem qualquer interferência no âmbito privado.

Ocorre que é importante destacar o alerta de HABERMAS (2006, p. 9), pois o Estado "não pode transformar o requisito institucional da separação entre religião e política em um 
indevido empecilho mental e psicológico para aqueles cidadãos que se orientam pela fé»15, sob pena de tolher a liberdade de convicção do crente e colocá-lo em circunstância de desigualdade, o que afronta as mais sublimes garantias do Estado Constitucional.

As diferentes concepções delineadas denotam caminhos divergentes na interpretação do direito fundamental à liberdade religiosa e influenciaram os países ocidentais, incluindo o Brasil. A Constituição de 1988 mantém a tradição brasileira - inaugurada no texto constitucional de 1934 - de apreço para com o fenômeno religioso, semelhante ao modelo constitucional dos Estados Unidos.

Desse modo, as múltiplas contendas que envolvem a preservação da liberdade religiosa no Brasil deve ser interpretada à luz do sistema constitucional, não apenas como um direito que impõe restrições à ação estatal, mas também como uma espécie que exige a participação do Estado, em nome do interesse social. Assim, pode-se compreender que "a laicidade não significa, por certo, uma inimizade com a fé”. (MENDES, COELHO, BRANCO, 2007, p. 318).

Portanto, em que pese o fenômeno religioso seja objeto de inúmeros casos difíceis que reivindicam a resolução pelo Estado, faz-se necessário ter em evidência que a liberdade religiosa somente será alcançada na medida em que for garantido o seu espaço no cenário público em situação de igualdade com as demais visões de mundo, em colaboração com o pluralismo social que revigora o sistema jurídico constitucional e democrático.

\section{BIBLIOGRAFIA}

ALTAFIN, Juarez. O cristianismo e a Constituição. Uberlândia: Editora Del Rey Ltda., 2007. ALVES, Othon Moreno de Medeiros. Liberdade religiosa institucional: Direitos humanos, direito privado e espaço jurídico multicultural. Fortaleza: Fundação Konrad Adenauer, 2008.

ARENDT, Hannah. A condição humana. Trad. Roberto Raposo. 10. ed. Rio de Janeiro: Forense Universitária, 2007.

\footnotetext{
15 Tradução livre. "The liberal state must not transform the requisite institutional separation of religion and politics into an undue mental and psychological burden for those of its citizens who follow a faith.”
} 
ARMSTRONG, Karen. Em nome de Deus: O fundamentalismo no judaísmo, no cristianismo e no islamismo. Trad. Hildegard Feist. São Paulo: Cia. Das Letras, 2009.

BARROSO, Luís Roberto. Fundamentos teóricos e filosóficos do novo direito constitucional brasileiro (pós modernidade, teoria crítica e pós positivismo). Revista da EMERJ, v. 4, n. 15, 2001.

BRASIL. Constituição da República Federativa do Brasil. Disponível em: $<$ http://www.planalto.gov.br/ccivil_03/constituicao/constitui\%C3\%A7ao.htm>. Acesso em: 01 dez. 2017.

CHAUÍ, Marilena de S. Espinosa: uma filosofia da liberdade. São Paulo: Moderna, 1995.

ESTADOS UNIDOS DA AMÉRICA. Declaration of Independence. Disponível em <http://www.ushistory.org/declaration/document/>. Acesso em 14 mar. 2018.

FRANÇA. Constituição. Disponível em: <http://www.conseil-constitutionnel.fr/conseilconstitutionnel/root/bank_mm/portugais/constitution_ portugais.pdf $>$. Acesso em $01 \mathrm{dez}$. 2017.

HABERMAS, Jürgen. Religion in the public sphere. European Journal of Philosophy 14:1, p. $1-25,2006$.

ÍSLAND, Háskóli; HUGVISINDASVID; FRAEDI, Frönk. La laïcité en France. Liberté de conscience?, 2015. Disponível em: <http://hdl.handle.net/1946/21554>. Acesso em 09 mar. 2018.

MACHADO, Jónatas E. M. Estado constitucional e neutralidade religiosa: entre o teísmo e o (neo)ateísmo. Porto Alegre: Livraria do Advogado, 2013.

. Liberdade religiosa numa comunidade constitucional inclusiva: Dos direitos da Verdade aos Direitos do Cidadão. Coimbra: Coimbra editora, 1996.

MARTINS, Leonardo. Liberdade e Estado Constitucional: leitura jurídico-dogmática de uma complexa relação a partir da teoria liberal dos direitos fundamentais. São Paulo: Atlas, 2012. 
MARTINS FILHO, Ives Gandra da Silva; NOBRE, Milton Augusto de Brito. O Estado laico e a liberdade religiosa. São Paulo: LTr, 2011.

MENDES, Gilmar Ferreira; BRANCO, Paulo Gustavo Gonet. Curso de direito constitucional. 9.ed. São Paulo: Saraiva, 2014.

SABORIT, Ignasi Terrades. Religiosidade na Revolução Francesa. Rio de Janeiro, 2009.

SANTOS JÚNIOR, Aloísio Cristovam dos. A laicidade estatal no direito constitucional brasileiro. Revista Jurídica Unifacs, maio, 2008. Disponível em <http://www.unifacs.br/ REVISTAJURIDICA/ARQUIVO/edicao_maio2008/convidados/con6.doc>. Acesso em 16 mar. 2018.

. Liberdade Religiosa, Igualdade, Tolerância e Proselitismo Religioso no Estado

Democrático de Direito. Disponível em <http://www.unifacs.br/revistajuridica/ arquivo/edicao_julho2008/convidados/con1.doc>. Acesso em 29 nov. 2017.

WOODS JR, Thomas E. Como a Igreja Católica construiu a civilização ocidental. São Paulo, 2008.

ZYLBERSZTAJN, Joana. O Princípio da Laicidade na Constituição Federal de 1988. 2012.

248 f. Tese (doutorado em Direito) - Faculdade de Direito da Universidade de São Paulo, São Paulo. 